Available online at: http://ejournal-balitbang.kkp.go.id/index.php/iaj

\title{
'YELLOW SYNDROME' IN SCLERACTINIAN CORALS THROUGHOUT BINTAN DISTRICT, KEPULAUAN RIAU PROVINCE, INDONESIA
}

\author{
Ofri Johan $\left.{ }^{*}\right)$, Agus Budianto**), and Michael J. Sweet ${ }^{* *+1}$ \\ ") Research Institute for Ornamental Fish Culture \\ *) Research Center for Oceanography-Indonesian Institute for Science. North of Jakarta \\ **a) Environmental Sustainability Research Centre, College of Life and Natural Sciences, University of Derby, UK
}

(Received 17 November 2016; Final revised 14 June 2017; Accepted 14 June 2017)

\begin{abstract}
Coral disease surveys were conducted in Bintan, Kepulauan Riau Province. The purpose was to identify the abundance of corals showing signs of Yellow Syndrome (YS) disease and to describe similar pathological signs to that of AYBD throughout Bintan District. Three belt transects ( $2 \mathrm{~m} \times 50 \mathrm{~m}$ in size) were set up to determine the abundance of coral reef attacked by YS disease. Line intercept transects were used to determine the percentage of live corals in the surveyed areas. The survey showed that the YS disease syndrome attacked 8 different genera i.e. Acropora, M ontipora, Porites, Pavona, Turbinaria, Favia, Platygyra, and Favites. The highest attack happened at Mapur Island $\left(0.06 \mathrm{kol} / \mathrm{m}^{2}\right)$ on Porites lutea, Turbinaria peltata, T. mesenterina, Acropora bruggemanni, and Pavona frondifera. The survey also indicated that there may have been at least two types of YS i.e. the first type caused by a boring and/or over-growing sponge species and the second type caused by a kind of pathogenic microbe. Regardless the causal agent of YS, the severity of YS attack on coral urged immediate action to be undertaken and should include initial microscopic and histology examinations. Based on this initial microscopic and histology examinations it was found out that YS bears a close resemblance to the Arabian Yellow Band Disease. This study, however, argued that the word "disease" may have been incorrectly used without identifying a specific causal agent.
\end{abstract}

\section{KEYWORDS: Arabian Yellow Band Disease; coral disease; sponge}

\section{INTRODUCTION}

Bintan District covers an area of over 8.6 million hectares of sea water with 240 small islands and three more densely populated islands, i.e. Bintan, Tambelan, and Mapur. Bintan District is the working area of the Coral Reef Rehabilitation and Management Program (COREM AP) which is currently monitoring the coral reef health. However, there have been no coral disease researches conducted so far. To date, only eight of 27 coral diseases have been reported and described i.e black band disease (Haapkylä et al., 2007; 2009, Johan et al., 2015a), white syndrome (Johan et al., 2015a; Haapkylä et al., 2007; Yusri \& Estradivari, 2007), skeleton eroding band (Haapkylä et al., 2007, Johan et al., 2015b), skeletal tumours (Haapkylä et al., 2007); Porites ulcerative white spot disease (Haapkylä et al., 2007); brown band disease (Haapkylä et al., 2009); and

\footnotetext{
\# Correspondence: Research Institute for Ornamental Fish Culture. Jl. Perikanan No. 13, Pancoran Mas, Depok 16436, West Java, Indonesian.

Phone: + (021) 7520482

E-mail: ofrijohan@yahoo.com
}

two diseases described as yellow band disease (YBD) (Muller et al., 2012, Subhan et al., 2011).

The term YBD was initially reported by Korrubel $\&$ Riegl (1998) when they described a novel disease affecting 10 different coral species in Dubai. They described the disease as a broad yellow band moving across healthy coral tissue and leaving behind bare skeleton in a manner similar to black band disease (Korrubel \& Riegl, 1998). Another disease case appeared in the Caribbean a year after this incident in Dubai (Santavy et al., 1999). The Caribbean version of YBD is now widely recognized as the term used to describe a disease that manifests itself as a round, pale yellowish blotch (also known as yellow-blotch disease in the past) which is surrounded by healthylooking tissue in central areas of the colony. This subsequently develops to a yellowish-pale tissue band at the colony edge or around depressed areas with sediment accumulation or algal growth (Santavy et al., 1999). Since this diseases initial description the word 'Caribbean' is inserted at the beginning of the disease name i.e. Caribbean yellow band disease - 
CYBD (Raymundo et al., 2008), to differentiate CYBD from other similar YBD diseases emerging throughout the Indo-Pacific (IP-YBD).

IP-YBD is currently under debate by research community. For example the term 'Arabian YBD' or AYBD is used to describe a yellow infliction on scleractinian corals in the Gulf (Riegl et al., 2012). However, AYBD shows few parallels to that of CYBD to the point where the names can be confusing and are often misinterpreted in disease surveys and publications. AYBD has been described to be fast spreading in Acroporid spp. and slower growing on Porites spp., while CYBD appears to only affect mussids (multiple genera), merulinids (Orbicella spp.), and montastraeids (Montatraea cavernosa). Tissue loss associated with CYBD is reportedly very slow, around $1-2 \mathrm{~cm}$ per month (Riegl et al., 2012). The signs of AYBD also differ from that of CYBD where corals inflicted with AYBD have bright yellow bands of one to several $\mathrm{cm}$ in width, which manifest themselves as circular lesions at the interface of healthy and dead coral. Furthermore, AYBD appears to manifest itself differently on different coral species; for example with a large yellow-greenish blotch on Porites, while a more characteristic band occurs on Porites harrisoni and the Acroporids. Also, the 'yellowish' coloration of AYBD appears to be raised above the surrounding tissue with thin mucous envelope covering the discoloration (Riegl et al., 2012).

This study was aimed to identify the abundance of corals showing signs of yellow syndrome (YS) disease and to describe similar pathological signs to that of AYBD throughout Bintan District, Kepulauan Riau of Bangka Belitung Province.

\section{MATERIAL AND METHOD}

Coral disease surveys were conducted during September 2014 and 2016. Surveys were conducted throughout the Bintan waters of Kepulauan Riau, Indonesia. The surveys included five different islands i.e. Beralas Bakau Island (Kril 85) $01^{\circ} 02^{\prime} 48.1^{\prime \prime N}$, 14040'31.8"E; Pangkil Kecil Island (Kril B) $00^{\circ} 55^{\prime} 22.8^{\prime \prime N}, 104^{\circ} 44^{\prime 2} 25.5^{\prime \prime}$; Mapur Island (Kril 14) $00^{\circ} 58^{\prime} 59.4^{\prime \prime N}, 104^{\circ} 47^{\prime} 39.6$ "E; Merapas Island (Kril 18) $00^{\circ} 55^{\prime} 39.6^{\prime \prime} \mathrm{N}, 104^{\circ} 55^{\prime} 24.0^{\prime \prime E}$ (Figure1). Mapur Island, is continuously surveyed and monitored annually for the overall conditions of coral reefs and any occurring socio-economic aspects (as part of the COREM AP initiative).

Data were collected using the belt transect and line intercept transect (LIT) methods the $50 \mathrm{~m} \times 1 \mathrm{~m}$ transects. Counts were conducted on both sides of the transect line with three replicated transects per site.

Belt transects method were conducted to obtain data on coral types and colony abundance showing signs of 'Yellow Syndrome' (YS). Abundance of YS was calculated from the number of infected colonies of each coral species per observation it $\left(100 \mathrm{~m}^{2}\right)$. Infected colonies were documented using underwater cameras (Canon Power Shot G15). Transects ran in parallel to the coastline at a depth of 5-7 $\mathrm{m}$ Line Intercept Transect method was used to obtain data on live coral coverage in the same area where the diseased corals were found (English et al., 1997).

Data were analyzed using Excell software to obtain percentage of live coral cover and mean of coral disease abundance. Descriptions of diseases and their signs were conducted by comparing the results of this study with previous publications on the same subject.

\section{RESULTS AND DISCUSSION}

Live coral coverage varied from $36 \%$ to $53 \%$ over the five sites surveyed. The highest coral coverage was found in Merapas (53\%, followed by Small Pangkil Island $(51 \%$, Mapur Island (46\%), and Beralas Bakau $(36 \%$. Colonies of Acropora were found at only three of the five sites but varied in abundance. The highest abundance was observed in Merapas Island waters $(40.70 \%)$ and low abundance occurred in both Mapur Island $(0.77 \%$ and Beralas Bakau Island $(0.60 \%$ waters.

At all sites, surveyed colonies were observed showing signs of a yellowing discoloration adjacent to healthy tissue (Figure 2). These signs were similar to those described by Riegl et al. (2012) who named these signs as Arabian Yellow Band Disease in their study Based on our study, however, we argued that these 'disease' signs should not fall under YBD category. Therefore, we suggested that in incidences where the causal agent is unknown, we should refer to the incidence as 'Yellow Syndrome' (YS) instead. At least nine different species of coral from seven genera shown was affected by YS in this study (Figure 2). The highest abundance of YS was found to be associated with colonies of Poriteslutea in two of the five locations i.e. Mapur Island and Merapas Island, although relative abundance was recorded as being low $\left(0.06 \mathrm{col} / \mathrm{m}^{2}\right.$ and $0.02 \mathrm{col} / \mathrm{m}^{2}$, respectively) (Figure 3). Colonies of Turbinaria mesenterina showed the second highest presence of YS, with abundances reflecting those found on P. lutea at Merapas Island. At Baralas Bakau Island, $0.02 \mathrm{col} / \mathrm{m}^{2}$ abundance of YS occurred on T. mesenterina which marginally increased 


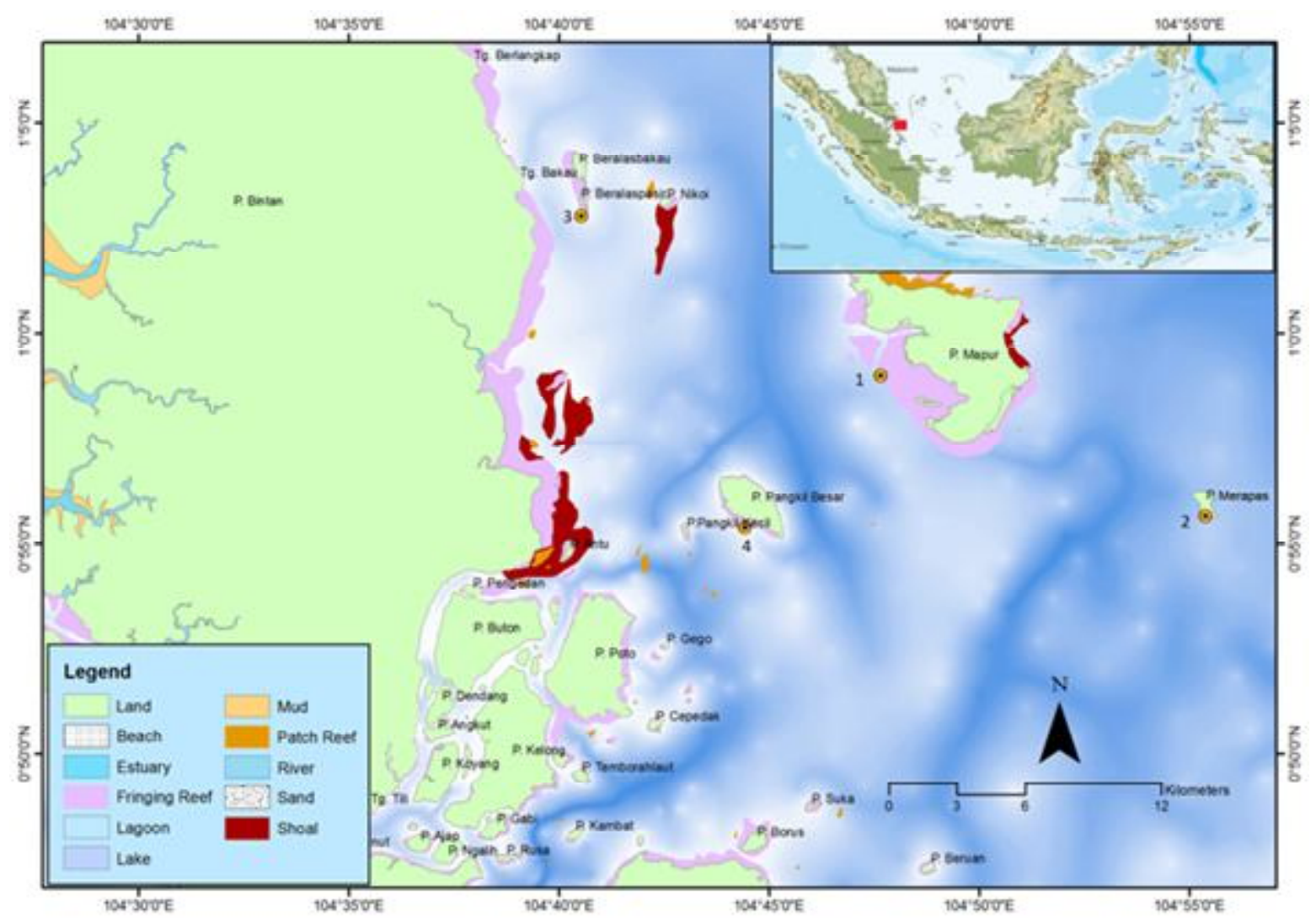

Figure 1. Locations of 'Yellow Syndrome' throughout Mapur Island (1), Merapas Island (2), Beralas Bakau Island (3), and Pangkil Kecil Island (4).

to $0.03 \mathrm{col} / \mathrm{m}^{2}$ at Pangkil Kecil Island (Figure 3). Other genera also showed low initial attack of YS throughout the four sites and these included; Acropora bruggemanni, Pavona frondifera, Turbina riapeltata, M ontipora crassituberculata, Porites cylindrica, Poritesrus, and Turbinaria frondens (Figure 2).

Instances of YS were also shown to follow a severe bleaching event occurred in 2016. In particular, colonies of Porites lutea, Favia sp., Platygyra sp., and Favites sp., appeared to be most susceptible to this syndrome (Johan \& Kusumah, 2016).

Previous study had described identical signs inflicting corals as described by this research and labeled the inflictions as a true coral disease (Riegl et al., 2012). Our research suggested caution in labeling the signs as true coral disease. Labeling these signs as YBD may lead to opinion that comparisons could be drawn between these signs and that of the Caribbean YBD, which is actually not the case.

Our research proposed the term 'yellow syndrome' to be used in a similar manner when describing any diffused pattern of tissue loss exposing irregular bands or patches of white skeleton throughout the Indo-
Pacific region i.e. 'white syndrome' (Bourne et al., 2014).

To date, there has been no work undertaken to identify the possible etiological agents for YS (the term used in this study) or AYBD (the previous term) (Riegl et al., 2012). Further studies should focus on describing possible pathological agents and environmental stress factors which trigger YS. From our initial observations, there were at least two 'types' of YS. The first one may have been caused by a boring and/or encrusting sponge species and the second one could be caused by a kind of pathogenic microbe.

Despite the currently unknown causal agents for YS, it is very important to investigate the prevalence of YS in different regions. Our study showed that YS was prevalent throughout Bintan Waters. However, the severity level was relatively low, which suggested these YS incidents as being initial attack to the coral reefs in Bintan Waters. Our study also showed that YS appeared to inflict nonspecific coral species with signs prevalent on eight genera i.e. Acropora, Montipora, Porites, Pavona, Turbinaria, Favia, Platygyra, and Favites. Previous study recorded four genera to 


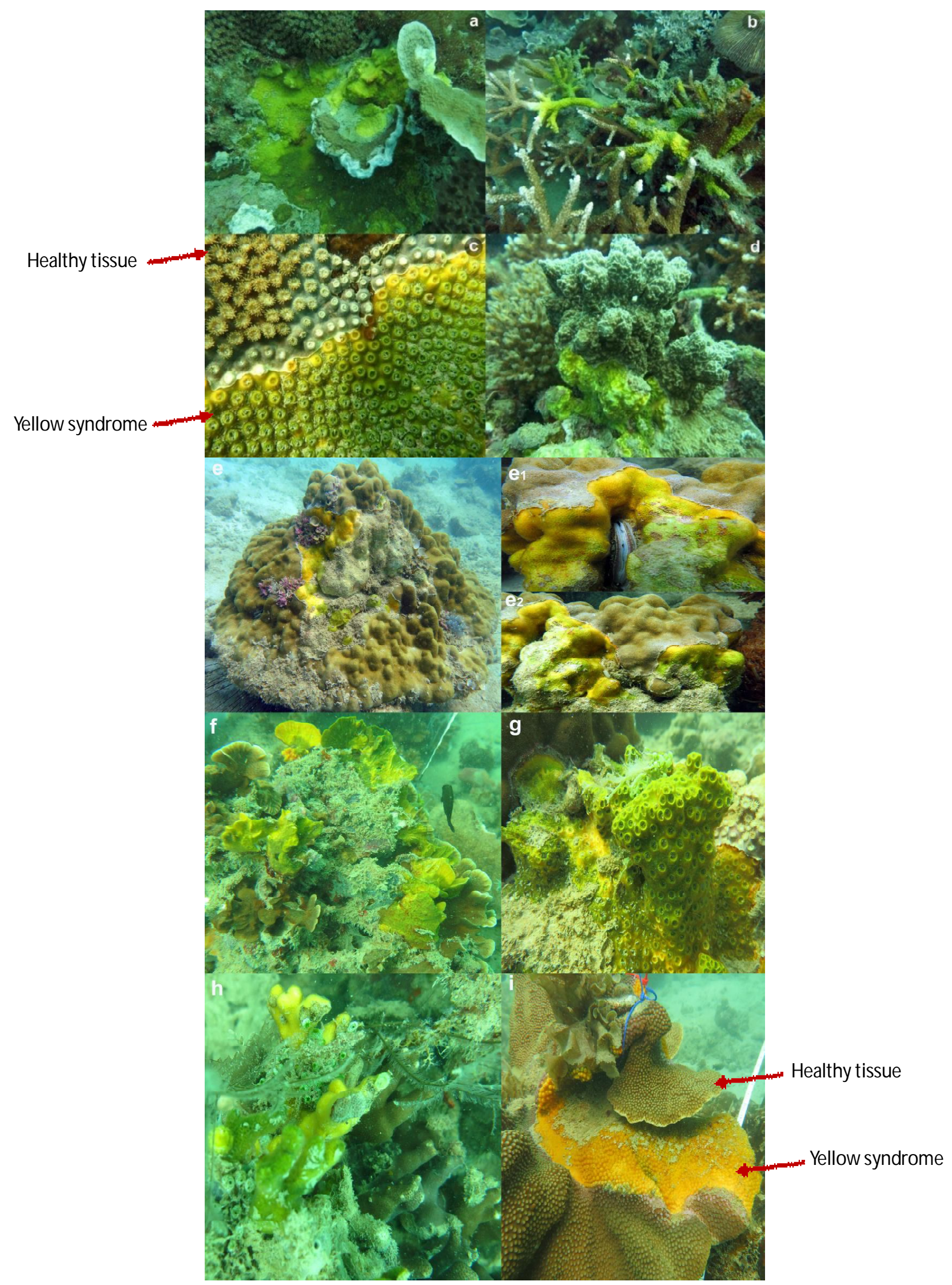

Figure 2. Corals showing different 'types' of 'yellow syndrome' on susceptible genera; (a) M ontipora tuberculosa, (b) Acropora brueggemanni, (c) Turbinaria frondens, (d) Porites rus, (e) Porites lutea, (f) Pavona frondens, (g) Turbinaria peltata, (h) Porites cylindrica, (i) T. mesenterina. 


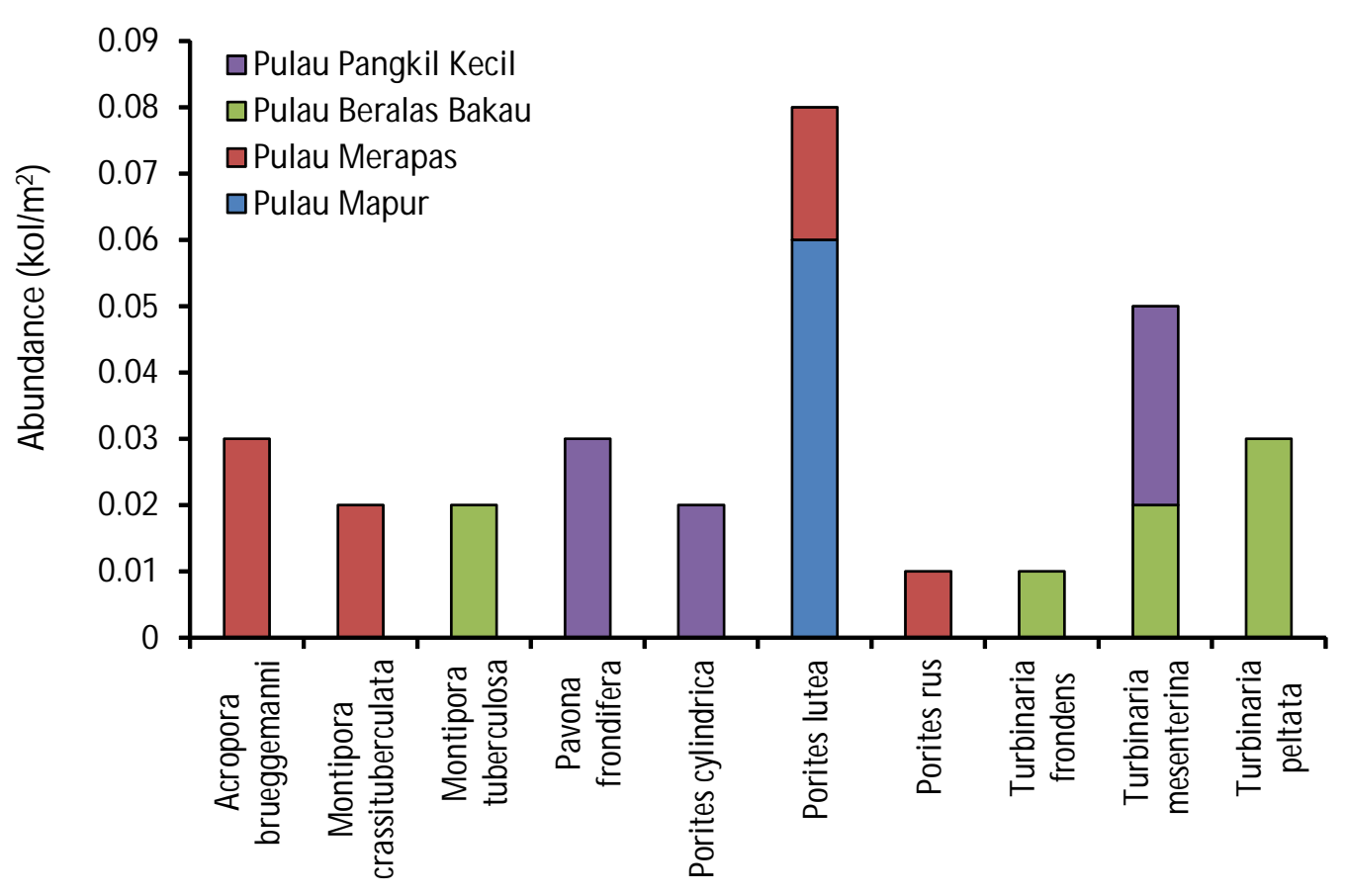

Figure 3. Yellow syndrome abundance throughout several islands in Bintan water.

be the host of YS i.e. Acropora, Porites, Turbinaria, and Cyphastrea (Riegl et al., 2012).

\section{CONCLUSION}

This study suggested the term 'Yellow Syndrome' (YS) should be used when describing yellow discoloration adjacent to healthy tissue, if the causal agent is unknown. This study also observed low but consistent incidents of YS throughout all surveyed sites in Bintan Waters. Future study should be conducted to determine causal agents for YS.

\section{Acknowledgements}

Author thank Esther Peters, Greta Aeby, Ernesto Weil, Bette Willis, and Laurie Raymundo for helpful discussions about YS and assistance with specific terminology associated with the yellow diseases. Thank are also extended for COREMAP (Coral Reefs Rehabilitation and Management Program) and the Research Center for Oceanography-Indonesian Institutefor Science for funding this project.

\section{References}

Bourne, D.G., Ainsworth, T.D., Pollock, F.J., \& Willis, B.L. (2014). Towards a better understanding of white syndromes and their causes on Indo-Pacific coral reefs. Coral Reefs, 34, 233-242.

English, S., Wilkinson, C., \& Baker, V. (1997). Survey manual for tropical marine resources, 2nd edn.
Townsville: Australian Institute of Marine Science, $368 \mathrm{pp}$.

Haapkyla, J., Seymour, A.S., Trebilco, J., \& Smith, D. (2007). Coral disease prevalence and coral health in the Wakatobi Marine Park, South-East Sulawesi, Indonesia. J. Mar.Biol. Assoc., 87, 403-414.

Haapkylä, J., Unsworth, R.K.F., Seymour, A.S., Melbourne-Thomas, J., Flavell, M., Willis, B.L., \& Smith, D.J. (2009). Spatio-temporal coral disease dynamics in the Wakatobi Marine National Park, South-East Sulawesi, Indonesia. Dis. Aquat. Org., 87, 105-115.

Johan, 0. \& Kusumah, G. (2016). Impact of SGD toward coral condition in North Lombok. Unpublish.

Johan, O., Bengen, D.G., Zamani, N.P., Suharsono, \& Sweet, M.J. (2015a). The distribution and abundance of black band disease and white syndrome in Kepulauan Seribu, Indonesia. Hayati J. Biosci., 22, 105-122.

Johan, O., Ginanjar, R., \& Priyadi, A. (2015b). Coral health of wild ornamental in East Belitung waters, Indonesia. Nusantara Biosci., 7(2), 127-132.

Korrubel, J.L. \& Riegl, B. (1998). A new coral disease from the southern Arabian Gulf. Coral Reefs, 17, 22.

Muller, E.M., Raymundo, L.J., Wilis, B.L., Haapkyla, J., Yusuf, Y., W ilson, J.R., \& Harvell, D.C. (2012). Coral health and disease in the Spermonde Archipelago and Wakatobi, Sulawesi. J. Indon. Coral Reefs, 1(3), 147-159. 
Raymundo, L.J., Couch, C.S., \& Harvell, C.D. (2008). Coral disease handbook: Guidelines for assessment, monitoring \& management. The Coral Reef Targeted Research \& Capacity Building for Management (CRTR), St Lucia, Qld. 121 pp.

Riegl, B.M., Bruckner, A.W., Samimi-Namin, K., \& Purkis, S.J. (2012). Disease, harmful algae blooms (HABs) and their effects on Gulft coral populations and communities.18 pp. In Riegl, B.M., \& Purkis, S.J.(eds). Coral reefs of the gulf: adaptation to climatic extremes, 107 Coral Reefs of the World 3. Springer, Berlin.
Santavy, D.L., Peters, E.C., Quirolo, C., Porter, J.W., \& Bianchi, C.N. (1999). Yellow-blotch disease outbreak on reefs of the San Blas Islands, Panama. Coral Reefs, 18, 97.

Subhan, B., Rahmawati, F., Arafat, D., \& Bayu, N.A. (2011). Coral health condition of Fungiidaein Pramuka Island waters, Kepulauan Seribu. Jurnal Teknologi Perikanan dan Kelautan, 2(1), 41-50.

Yusri, S. \& Estradivari. (2007). Distribution of infection by white syndrome and coral bleaching to coral communities in Petondan Timur Island, Kepulauan Seribu. Berita Biologi, 8(4), 224-229. 